\title{
The Comparison of the Excise Tax Policy for Human Development in ASEAN
}

\author{
M. Zainul Abidin ${ }^{1}$ \\ ${ }^{1}$ Ministry of Finance of Indonesia \\ Email: abidinmz@gmail.com
}

\section{ARTICLE INFORMATION}

Received date

[22-11-2019]

Revision

[06-12-2019]

Accepted date

[06-12-2019]

\begin{abstract}
:
The purpose of this paper is to examine the excise policy to support human development in the ASEAN Member States (AMS). This study uses a qualitative method. The results showed that the excise tax policy had supported human development in AMS. The human development index in AMS has improved supported by an increase in the health and longevity index, as experienced by Singapore, Brunei Darussalam, Malaysia, and Thailand. This is supported by the existence of an excise tax policy that imposes high tariffs and is imposed on various types of negative products. AMS has implemented an excise policy to protect the health of its citizens through restrictions on the consumption of products that have a negative impact on the health of individuals and society. Goods subject to excise related to health protection include: cigarettes, alcoholic beverages and sweetened beverages. The excise policy in AMS varies with the excise tax rate and the types of goods subject to excise duty. Countries that charge relatively high excise tax rates include: Singapore, Brunei Darussalam, Malaysia, and Thailand. The countries that charge the most variety of negative products are Brunei Darussalam, Malaysia, the Philippines and Thailand.
\end{abstract}

Keywords: ASEAN, Excise polic, health, human development, productivity 


\section{INTRODUCTION}

The ASEAN region has grown to become one of the regions that has developed and achieved high economic growth (ASEAN Secretariat, 2018). In 2017, ASEAN economic growth reached 5.3\%, higher than global economic growth of 3.7\% (IMF, 2018). This increases the per capita income and purchasing power of the ASEAN people (Figure 1). The growth in purchasing power is driving higher levels of consumption.

ASEAN recorded a significant growth in consumption of goods ( $\mathrm{PwC}, 2018)$. The use of consumer goods is very popular in the community. However, a number of the consumer goods are considered to be harmful to health and the environment (Li \& Suh, 2019). Health and environmental risks threaten the surrounding living things. However, the behavior patterns of some people are not aware of the negative impact of the use of some consumer goods. In addition, the ease of obtaining consumer goods can in fact increase risks for individuals, society and the environment. A number of problems resulting from the behavior of consuming negative products can reduce productivity, income and society well-being (Guthrie et al., 2015)

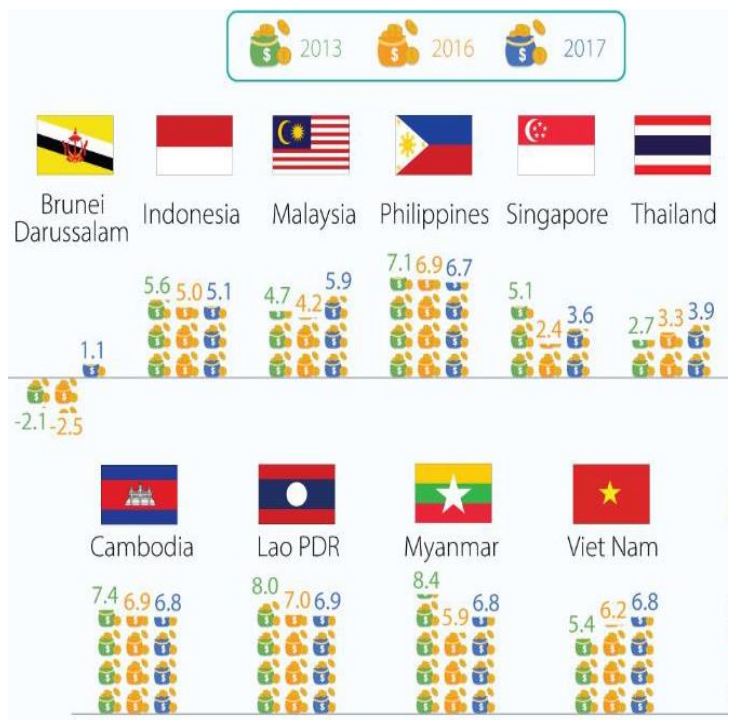

Figure 1. ASEAN Member States GDP Growth at Constant Prices (\%) Source: ASEAN Secretariat, 2018

Tobacco, alcohol, and sugary beverage consumption accounts for a big and increasing share of the world's burden of early death and disease. Consuming these products escalate the risks of noncommunicable diseases (NCDs) that result in early death, productivity losses, avoidable healthcare costs, and household poverty (Task Force on Fiscal Policy for Health, 2019). 
Restrictions on the consumption of certain goods are intended to reduce the negative impact of these goods on individuals, communities and the environment. With this limitation, it is expected that human and environmental quality will be maintained / improved. Human resources and environmental sustainability support economic development and the welfare of its citizens.

ASEAN Member States (AMS) has policies to reduce the circulation of some consumer goods through taxation to reduce the risk of consumption of certain goods. The policy adopted by AMS for the negative impact of a product is carried out, one of which is through the imposition of excise on certain products. ASEAN Member States that have restricted the circulation of consumer goods through excise policies: Brunei Darussalam, Cambodia, Indonesia, Laos, Malaysia, Myanmar, the Philippines, Singapore, Thailand, and Vietnam (Preece, 2019).

ASEAN Member States are heading for efforts to increase economic growth to improve the welfare of their people. These efforts can be through fiscal policy instruments. The governments of ASEAN Member States to overcome social and environmental problems through the imposition of excise duties. Therefore, ASEAN Member States impose excise duties to achieve development goals. Excise tax policy in addition to the regulating function, also to increase state revenue. Imposition of excise can increase state revenue while protecting the public. ASEAN Member States has applied excise according to social and political conditions because the levies are stipulated within a framework of political institutions.

The excise policy basically protects the public from the risk of consuming / using certain items. This policy is considered beneficial for the state budget, the general public and the environment. However, there are no studies that examine the relevance of excise tax policies do support human development in ASEAN Member States. Excise policy can protect the quality of human resources from adverse effects due to consumption of certain products. The quality of human resources, measured through the human development index, is an important component to support a country's economic Development (Teixeira \& Queirós, 2016). However, there is no study/literature linking the excise tax policy and the quality of human resources in ASEAN Member States.

The research gap between excise and human quality is the main interest of the author to conduct a study of excise policy for human development in ASEAN. The objectives of the study to examine excise policy to support human development in the ASEAN Member States (AMS). 


\section{LITERATURE REVIEW}

\subsection{Excise Taxes}

In general, excise can be regarded as a tax imposed on certain goods (selective taxes on goods) (Rosdiana and Irianto, 2012). In other word, excise is a levy on the delivery of goods such as tobacco-based products, alcoholic beverages, petroleum products, motor vehicles, pollution-causing activities, luxury items and other items specifically defined by the provisions of the goods domestic and imported production (Drozdek, 2019). Basically, the initial concept of imposing excise originated from a convention carried out by the Anglo-Saxon state, where excise was described as taxing on manufacturing activities.

Taxes are state levies imposed on certain goods that have the characteristics or characteristics specified in the Tax Law. In the traditional collection system, luxury items (such as jewelry, luxury watches, and perfumes) are often taxed. In addition, in some countries, taxation is also imposed on semi essential goods such as soft drinks, various types of entertaining activities, gambling, and provision of airport services.

Excise and consumption tax differ in terms of the object, the purpose of the imposition, the level of imposition, the type of tariff and the form of supervision. As a distinction between excise and tax on consumption known as Value Added Tax in Indonesia or broadly as Value Added Tax / Sales and Goods Tax as follows:

Table 1. The Difference between Excise and Sales Tax

\begin{tabular}{ccc}
\hline Criteria & Excise & Sales Tax \\
\hline Object & $\begin{array}{c}\text { Selective in } \\
\text { coverage }\end{array}$ & General taxes \\
$\begin{array}{c}\text { Purpose of } \\
\text { collection }\end{array}$ & $\begin{array}{c}\text { Discrimination } \\
\text { in intent }\end{array}$ & Revenue purposes \\
Monitoring & $\begin{array}{c}\text { Quantitative } \\
\text { measurement }\end{array}$ & Self assessment \\
Imposition & $\begin{array}{c}\text { Single stage } \\
\text { Unit tax or } \\
\text { Imposition of } \\
\text { tariff }\end{array}$ & $\begin{array}{c}\text { Multistage } \\
\text { multi tax rate } \\
\text { tax or advalorem } \\
\text { tax }\end{array}$ \\
\hline
\end{tabular}

Source: Rosdiana \& Irianto, 2012.

The purposes of excise taxation are: (a) increasing revenue, (b) reflecting large externalities costs associated with consumption or production of goods (for example on 
cigarettes, alcoholic beverages, pollutants), (c) reducing consumption potential to cause negative effects, (d) to charge fees for services provided by the government, (e) to increase the progression of taxation on luxury goods (Cnossen, 2015).

Excise tax is one of the important fiscal instruments for state authorities. Excise tax is one type of indirect tax, which is a tax that can be imposed on product users and repeatedly (Cristea, 2017). Categorize a tax, the types of direct or indirect taxes, namely by paying attention to the three tax elements as follows (Schneider, 2015):

a. Taxpayers, those who are formally juridical must pay taxes.

b. The taxpayers, that is, the person who real bears the tax burden that must be paid first.

c. Tax bearers, those who according to the law must be taxed.

If the three elements are present in a person, then the tax paid is categorized as direct tax, but if one of the elements is separated from more than one person, the tax paid is categorized as indirect tax.

Excise levies collected by the authorities are indirect tax, because the tax subject elements as described above are more than one person. Furthermore, the position of the tax guarantor and the real tax guarantor are manufacturer who produce excisable goods, while the final tax bearer is the consumer as the end user of the excisable goods. There are three basic concepts of universal taxation, namely (Ismer \& Piotrwki, 2018):

a. Selectivity in coverage

The selection of excise objects is limited (selectivity) and the determination of the level of excise tax for each product that is levied is carried out separately according to the basic purpose of the imposition of excise.

b. Discrimination in intense

Excise tax is intended for certain purposes desired by government authorities so that a product is not freely consumed by the public.

c. Some form of quantitative measurement

The design of excise taxing usually has implications for several forms of physical supervision. This is intended to determine tax liability and ensure that subjects are subject to compliance with the law.

State revenue derived from excise is intended to create prosperity, justice and balance in society. While for manufacturers, excise tax policy aims to provide opportunities to adjust their production, in the sense of limiting or reducing the levels of production and considered harmful to health (Maulana, 2019). The nature of these goods is destructive and addictive. The purpose of the characteristics of excisable goods is to have special characteristics 
compared to other products consumed by the public. Special characteristics of the goods subject to the excise because it threatens the human body so it needs to be controlled so that its use is not widespread. Goods subject to excise have the following characteristics (Maulana, 2019):

a. Consumption needs to be controlled.

b. Circulation needs to be monitored.

c. Having a negative impact.

d. Its use requires the imposition of state levies for justice and balance.

Excise tax is suitable to be used as an instrument to control consumption, especially in developing countries because the pattern of consumption behavior of people tends to be price sensitively. If the tax burden is applied in the right amount, then the consumption pattern of the people will tend to decrease (Mononi, 2015). The excise system is as follows (Iglesias, 2016):

a. Advalorum excise tax or percentage

In the advalorum tariff system, excise tax is calculated based on a certain percentage multiplied by a certain basic price. The advantage in the Advalorum tariff system is that it is easy to keep abreast of market prices. The difficulty faced by the government with regard to the implementation of the Advalorum excise tax system is in the field of supervision.

b. Specific Excise Rates

In a specific excise tax system, excise tax is calculated by multiplying the excise tax rate in currency units with a certain number of specific units. The advantage of the specific tariff system is relatively facilitating the supervision of the circulation of Excisable Goods in the market. The disadvantage a specific tariff system is the nature of specific tariffs that cannot keep up with market prices.

Taxes can cause a shift in the use of goods (consumption). The shift in demand is to change the pattern of consumption so that goods consume lower price due to lower tax rates or switch products (Falbe et al., 2016). The effect of taxes on the consumption is influenced by the elasticity of demand for the goods. Goods that are perfectly elastic in demand will not be affected by taxation. The consumer will pay the entire tax burden added to the price of the item. Conversely, if the elasticity of demand for goods is perfect, the company cannot shift its tax burden on the price of goods (Falbe et al., 2016).

Individual reactions to tax are determined more by the elasticity of the income. For low income groups, the demand for income is usually high. So that the elasticity is high 
where as income decreases, it will actually discourage willingness to buy. As for those who are less concerned with luxury lifestyles, their demand for income is low so that the elasticity of demand in relation to income is also low (Ho et al., 2018).

\subsection{Human Development}

In 1990, UNDP (United Nations Development Program) in its report "Global Human Development Report" introduced the concept of "Human Development" as a new paradigm of development models. According to UNDP, human development is formulated as an enlarging the choices of people, which can be seen as a process of efforts towards "expanding choices" and at the same time as a level achieved from these efforts. At the same time human development can also be seen as the formation (formation) of human capabilities through improving the level of health, knowledge, and skills; as well as the utilization (utilization) of their abilities / skills.

The concept of development above is much broader than the concept of economic development which emphasizes growth (economic growth), basic needs, community welfare, or human resource development. UNDP, in the 1995 Human Development Report (HDR), emphasized that to expand human choices, the concept of human development must be built from four inseparable dimensions. Based on the above concept, to ensure the achievement of human development goals, there are four main elements that need to be considered (UNDP, 1995), namely:

a. Productivity. Communities must be able to increase their productivity and participate fully in the process of finding income and employment. Therefore, economic development is part of the human development model.

b. Equity. The community must have access to fair opportunities. All barriers to economic and political opportunities must be removed so that people can participate in and benefit from existing opportunities.

c. Sustainability. Access to opportunities must be ensured that not only for present generations but also for future generations. All types of capital be it physical, human, and the environment must be equipped.

d. Empowerment. Development must be carried out by the community, and not just for them. Communities must fully participate in making decisions and processes that affect their lives.

The concept of complete human development is a concept that requires an increase in the quality of life of the population both physically, mentally and spiritually. Even explicitly stated that the development carried out focuses on the development of human resources in 
line with economic growth. Development of human resources physically and mentally implies an increase in the basic capacity of the population which will then enlarge the opportunity to be able to participate in a sustainable development process. Human Development Index, because it is intended to measure the impact of efforts to improve these basic abilities, thereby using the impact indicators as a basic component of its calculation, namely life expectancy at birth, educational attainment measured by literacy rates and average length of schooling, and expenditure consumption.

The HDI began to be used by UNDP to measure efforts to achieve the country's human development. Although it cannot measure all dimensions of development, it is able to measure the basic dimensions of human development which are considered to reflect the status of basic capabilities of the population. HDI is calculated based on data that can describe the four components, namely life expectancy representing the health sector, literacy rates and average length of schooling measuring development achievements in education, and the purchasing power / purchasing power parity (PPP) of the community towards a number of basic needs as seen from the average amount of per capita expenditure as an income approach that represents development achievements for a decent life.

The concept of HDI was first published by UNDP through the 1996 Human Development Report, which then continues every year. In this publication human development is defined as "a process of enlarging people's choices" or processes that improve aspects of people's lives. The most important aspects of life are seen from a long and healthy life, an adequate level of education, and a decent standard of living. Specifically, UNDP defines four main elements in human development, namely productivity (equity), equity (equity), sustainability (sustainability), and empowerment (empowerment). Based on the concept of Human Development developed by the United Nations (United Nations), ranks the performance of human development on a scale of $0.0-100.0$ with the following categories: a) High: HDI of more than 80.0 b) Upper Medium: HDI between 66.0 - 79.9 c) Lower Intermediate: HDI between 50.0 - 65.9 d) Low: HDI less than 50.0.

In the Human Development Index (HDI) there are three composite indicators used to measure the average achievement of a country in human development, namely: length of life, as measured by life expectancy at birth; education measured based on average length of schooling and literacy rates of people aged 15 years and over; standard of living measured by per capita expenditure that has been adjusted to purchasing power parity. This index value ranges from 0-100. The definition of HDI issued by UNDP which states that the 
Human Development Index (HDI) or Human Development Index (HDI) is one approach to measure the success rate of human development.

The HDI value of a country or region shows how far the country or region has reached the determined target, namely the life expectancy of 85 years, basic education for all levels of society (without exception), and the level of expenditure and consumption that has reached a decent standard of living. Human capital formation is a process of obtaining and increasing the number of people who have the expertise, education, and experience that is decisive for the economic development of a country. The formation of human capital is therefore associated with investment in humans and its development as a creative and productive source.

Although HDI is a measurement tool for HR development that is constantly being formulated, it is recognized that it will never capture the Figure of HR development perfectly. The indicators chosen to measure HDI dimensions are as follows (UNDP, Human Development Report 1993: 105-106):

a. Longevity, measured by the variable life expectancy at birth or life expectancy of birth and the infant mortality rate per thousand population or infant mortality rate.

b. Educational Achievement, measured by two indicators, namely literacy of the population aged 15 years and over (adult literacy rate) and the average year of schooling for residents 25 and above (the mean years of schooling).

c. Access to resources, can be measured macro through real GDP per capita with the terminology of purchasing power parity in US dollars and can be supplemented by the level of the workforce.

In the human development index, there are three composition indicators used to measure the size of a country's human development index, namely: a) The level of health is measured life expectancy at birth (infant mortality rate). b) Education level is measured by literacy rate (with a weight of two-thirds) and average length of schooling (with a weight of one third). c) Living standards are measured by per capita expenditure per year. From this explanation it can be concluded that the components that influence HDI:

a. Life Expectancy Index. Life expectancy index shows the number of years of life that are expected to be enjoyed by residents of a region. By entering information about birth and death rates per year, this variable is expected to reflect the average length of life as well as the healthy life of the community. In connection with the difficulty of getting information on people who died at a certain time, then to calculate the life expectancy used an indirect method. The basic data needed in this method is the average number of 
children born alive and the average number of children still alive from ever-married women. In short, the process of calculating life expectancy is provided by the Mortpak program. To get the life expectancy index by standardizing the life expectancy against the maximum and minimum values.

b. Decent Living Index to measure the dimensions of decent living standards (purchasing power), UNDP uses an indicator known as real per capita GDP adjusted.

c. Education Index Calculation of Education Index (IP) includes two indicators namely literacy rate (LIT) and average length of schooling (MYS). The population used is residents aged 15 years and over because in reality there are those who have stopped schooling. This limit is needed so that the figure reflects the actual condition considering that the population aged less than 15 years is still in the process of going to school or going to school so it is not appropriate for the average length of school. These two education indicators are raised in the hope that they will reflect the level of knowledge (a reflection of LIT figures), where LIT is the proportion of the population who have literacy in a population group as a whole. While the reflection of MYS figures is a Figure of the skills possessed by the population.

According to Todaro (2006: 187), there are three universal components of human development as the main objectives include:

a. Adequacy, which is a basic human need physically. Basic needs are those that if not met will stop a person's life, including food, clothing, shelter, health and safety. If one is not fulfilled it will cause absolute backwardness.

b. Identity, which is a component of a better life is the urge of oneself to move forward, to respect oneself, to feel worthy and worth pursuing something, and so on. All of that is summarized in self-esteem.

c. Freedom from Respect, which is the ability to have universal values listed in human development is human freedom. Independence and freedom here are defined as the ability to stand tall so that it is not enslaved by the pursuit of material aspects in life. With freedom we are not only chosen but we choose.

HDI can be used for several things as follows:

a. To divert the focus of the attention of decision makers, the media and non-governmental organizations from the use of ordinary economic statistics, to put more emphasis on human achievement. HDI was created to emphasize that humans and all their abilities should be the main criteria for assessing the development of a country, not economic growth. 
b. To question a country's policy choices. How can two countries with the same per capita income levels have different HDI.

c. To show differences between countries, between regions, between gender, ethnicity, and other socio-economic groups. By showing disparities or disparities between these groups, various debates and discussions will be born in various countries to find the source of problems and solutions.

\section{RESEARCH METHODS}

This study used a qualitative approach. Based on the research objectives, this study was a descriptive study. Descriptive research is done to provide a more detailed Figure about a phenomenon. The purpose of descriptive research is to describe the mechanism of a process, presenting basic information, describes the stages or a set order, and create a set of categories or patterns.

To achieve research objectives, this study conducted a literature study (library research). The data obtained are secondary data that can be used as a foundation review to analyze the problems. Data analysis is the process of simplification of data into a form that is easier and simpler. Data analysis technique used is qualitative data analysis techniques. Qualitative data analysis is the effort made by working with the data, organize data, sorted them into units that can be managed, synthesize, search and find patterns, find what is important and what is learned, and decide what can be told to others.

\section{ANALYSIS AND DISCUSSION}

\subsection{Excise Taxes in ASEAN}

ASEAN member countries have a number of excise tax provisions. In general, it can be categorized into groups: Food / beverage products, production goods, dangerous goods group, luxury goods group, entertainment and gambling goods, and miscellaneous services.

The International Tax and Investment Center (ITIC) clearly explains the best practices and design of excise tax policies on excise products such as alcoholic beverages, motor vehicles, tobacco products, and other excise products. Excisable products in the food / beverage category and dangerous goods group are listed in Table 2.

Table 2. Excisable Products

\begin{tabular}{ccc}
\hline Country & Food / beverage products & Dangerous goods \\
\hline Cambodia & $3 \%$ for meat products (slaughter) & - \\
Indonesia & Sugar & -
\end{tabular}




\begin{tabular}{|c|c|c|}
\hline Country & Food / beverage products & Dangerous goods \\
\hline Laos & $30 \%$ liquor & $70 \%$ playing card \\
\hline Malaysia & $\begin{array}{c}\text { Sugar, confectioner's sugar, } \\
\text { vinegar }\end{array}$ & - \\
\hline Myanmar & Sugar and salt & Matches \\
\hline Philippine & Saccharin & Matches \\
\hline Singapore & Water & - \\
\hline Thailand & Soft drinks, juice & $\begin{array}{c}\text { Lighters, mechanical lighter, playing } \\
\text { card }\end{array}$ \\
\hline Vietnam & - & $30 \%$ playing card \\
\hline
\end{tabular}

Source: Asia Pacific Tax Forum (ATPF), 2013

In general, indirect taxation in the form of excise tax is applied in all ASEAN countries, even though the names used may vary. Goods subject to excise also vary, and so is the basis for the imposition of excise; although there are also similarities in excise tax policy and administration. For example, in terms of products, there are five products that are subject to excise tax (or other names that have the same aim) in all ASEAN countries, namely beer, wine, spirits, cigarettes, cigars, and passenger vehicles. There are also several products that are subject to excise duty in the majority of ASEAN countries (for example $\mathrm{BBM}$, trucks, buses, motorbikes, and nightclubs), and there are also products in only one ASEAN country, such as kretek excise in Indonesia (APTF, 2013).

In detail, the items that are categorized subject to excise by the Asia Pacific Tax Forum-ASEAN Excise Tax Study Group as of 2013 as follows:

Table 3. Items That are Categorized Subject to Excise

\begin{tabular}{lll}
\hline \multicolumn{1}{c}{$\begin{array}{c}\text { All } \\
\text { Countries }\end{array}$} & \multicolumn{1}{c}{$\begin{array}{c}\text { Most } \\
\text { Countries }\end{array}$} & \multicolumn{1}{c}{$\begin{array}{c}\text { At Least One } \\
\text { Country }\end{array}$} \\
\hline Beer, & Gasoline, & Non-alcohol \\
wine, & diesel, & beverages, \\
distilled & kerosene, & kreteks, \\
spirits, & RYO & LPG/CNG, \\
cigarettes, & tobacco, & ethanol, luxury \\
cigars, & pick-up & goods, home \\
passenger & truck, & electrical goods, \\
vehicle & buses, & eco goods, \\
\hline
\end{tabular}




\begin{tabular}{ccl}
\hline $\begin{array}{c}\text { All } \\
\text { Countries }\end{array}$ & \multicolumn{1}{c}{$\begin{array}{c}\text { Most } \\
\text { Countries }\end{array}$} & \multicolumn{1}{c}{$\begin{array}{c}\text { At Least One } \\
\text { Country }\end{array}$} \\
\hline & motorcycle, & gambling, \\
night club & golf/recreation \\
& venues & \\
\hline
\end{tabular}

Based on the framework of the realization of the free flow of goods and services, different administrative systems, types of products, and different tariffs in ASEAN countries can hamper the flow of goods and services. For example, for tobacco products, ASEAN countries with low excise tariffs can become production base targets, while ASEAN countries with high retail sale prices can become export targets (Budilaksono and Rustiningsih, 2013). In addition to inhibiting the flow of goods and services, increasing cross-border trade or smuggling, these differences can also encourage competition in taxation policies among ASEAN countries. As happened in Europe, the implementation of the single market initially resulted in excise tax competition and changes in strategic interactions among EU member states, particularly in alcoholic beverage products (Le Cacheux \& Laurent, 2015).

In some ASEAN countries, even the naming of excise duty still uses different terminology. In an international context, excise is known as "Excise", but this is not the case in Vietnam. Vietnam uses a "special consumption tax", Thailand specifically levies a "liquor tax" on alcohol and "tobacco tax" on tobacco. Meanwhile, it must be stressed again that excise is not a sales tax that is imposed on each line of delivery of goods or services. In addition, the types of goods or services that are subject to excise duty are also very varied in each country. Meanwhile, the imposition of excise tariffs in several ASEAN countries also varies as in the Table 4:

Table 4. Basic of Imposition of Excise

\begin{tabular}{ccc}
\hline & Use of Ad & \\
Use of Specific rates & valorem & Use of mix rates \\
& rates & \\
\hline Brunei; Indonesia; & Cambodia; & Malaysia; Philippines \\
Philippines (for beer, & Laos; & (for liquor); Thailand \\
wine and cigarettes); & Myanmar; & (for beer, wine and \\
Singapore & Vietnam & liquor) \\
\hline
\end{tabular}

Source: Asia Pacific Tax Forum (ATPF), 2013 
In terms of the excise system, there are ASEAN countries that adhere to ad valorem tariffs, specific rates (including Indonesia), or mixed rates. The most obvious difference is the amount of excise tax rates that differ between ASEAN countries. In general, all ASEAN member countries impose indirect taxes in the form of excise, although the terms used in each country may differ. Goods subject to excise duty and the basis for the imposition of excise can also be different. Nevertheless, in terms of products, there are 5 types of goods subject to excise duty in all ASEAN countries, including beer, wine, spirits, cigarettes, cigars, and motor vehicles. Meanwhile, there are also excisable goods (BKC) which are only found in one ASEAN country, namely kretek excise in Indonesia. In terms of the excise system, there are ASEAN countries that adhere to ad valorem tariffs, specific tariffs, and mixed tariffs.

The excise tax policy supports economic growth and higher state income in the ASEAN region. There are various kinds of data related to various types of excise and the contribution of revenue from year to year in ASEAN member countries. Not only that, there are several types of excise tax application in ASEAN countries. The excise tax is designed to fulfill various objectives such as increasing state income, for health, environmental, economic, employment or other social purposes which differ among ASEAN member countries.

The development of ASEAN economic integration is considered to increase coordination and cooperation in each excise tax policy. Coordination is needed to avoid differences in tax policies that affect consumers' decisions in buying an item or production location decisions that lead to unfair trade competition. Excise tax in ASEAN plays an important role in correcting negative externalities and increasing state revenue (Preece, 2015).

The average contribution of tax revenue to ASEAN state tax revenues is around $10 \%$ in Indonesia, Vietnam, Malaysia and the Philippines. Meanwhile, the contribution of tax revenue to tax revenue reached $20 \%$ in Laos, Thailand and Cambodia which reached 20\% (APTF, 2013). One of the most important matters discussed is the emphasis on national tax sovereignty. That is, every country in the ASEAN region has full sovereignty to determine the best excise tax system for each country.

There is no common understanding of the excise tax policy priority to protect health due to the varied excise tax object among ASEAN countries. ASEAN countries need to prioritize the harmonization of policies between revenue and public health. Excise tax extensification is needed to increase state revenue and protect public health. 


\subsection{Human Development in ASEAN}

In 1999 the HDI ranking in Indonesia was still very low, which ranked 105th out of 162 countries and ranked 6th among ASEAN countries. This ranking is still below other ASEAN countries, but the HDI in Indonesia is still above the ranking of Vietnam, Myanmar, and Cambodia. Singapore ranks among the ASEAN countries, followed by Brunei, Malaysia, Thailand and the Philippines. In the following years, Indonesia's ranking continued to decline, even Vietnam's HDI ranking surpassed Indonesia starting in 2002. Indonesia's HDI ranking has only been slightly higher than Vietnam, Myanmar, and Cambodia since that year until 2011. (Kuncoro, 2015). In the Development report Humans by UNDP, in 2015 recorded the HDI of Indonesian countries at 113 levels out of 188 countries in the world.

Since 1990, UNDP has always recorded the development of the Human Development Index (HDI) in various countries. This calculation is carried out with the aim of comparing human development achievements between countries in the world. In 2014, UNDP recorded the Human Development Index in Indonesia reaching 68.38. HDI 2014 experienced an increase of 0.27 from the previous year. Indonesia in 2014 assumed the title "Medium" in human development. Although Indonesia entered the "Medium" category of human development, Indonesia was ranked 110th out of 188 countries in 2014. Meanwhile, in ASEAN Indonesia was ranked 5th after Singapore, Brunei Darussalam, Malaysia, and Thailand.

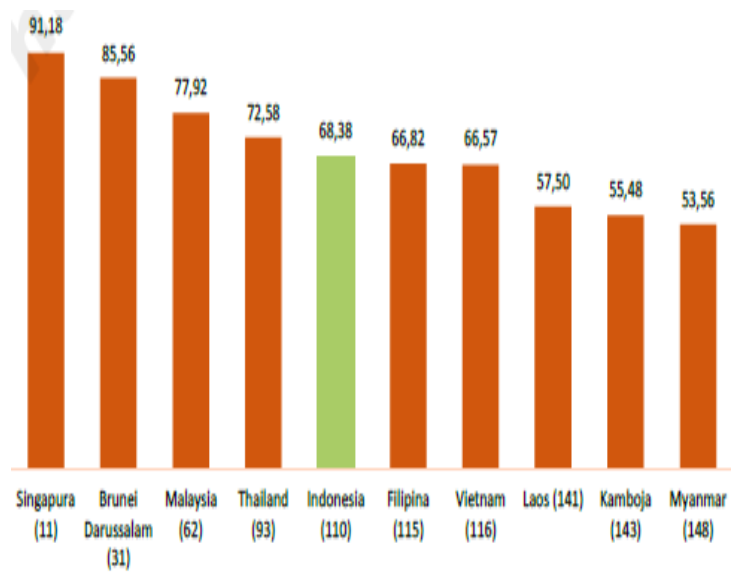

Figure 2. The ASEAN Human Development Index, 2014

Source: UNDP, 2015

Of the four countries which occupy positions above Indonesia, Singapore and Brunei Darussalam have shot far in the "Very High" category. While the other two countries, Malaysia and Thailand are already in the "high" category. Indonesia is still in the "medium" 
category along with Vietnam and the Philippines. In addition, there are three countries that still survive in the "Low" category, namely Laos, Cambodia and Myanmar.

Human development in ASEAN is also not immune from the gap. UNDP noted that in 2014, the Human Development Index in Singapore had reached 91.18. When compared with Indonesia, there are differences in achievements by 22.80 points. This is caused by all components of HDI in Singapore which are much better when compared to Indonesia.

\subsection{Excise Taxes and Human Development in ASEAN}

Figure 3 shows that Singapore, Brunei Darussalam and Malaysia are in the very high HDI category. Thailand is in the high category. Meanwhile, the remaining six AMS are in the medium HDI category.

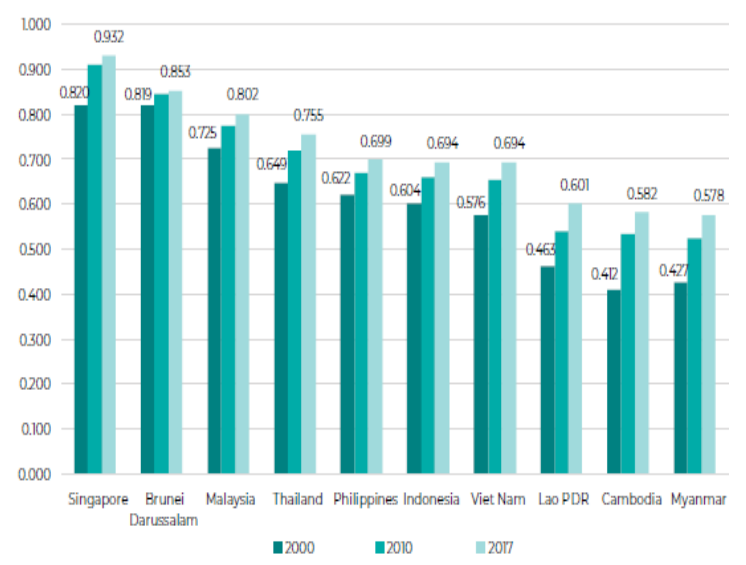

Figure 3. Human Development Index by ASEAN Member States, 2000-2017 Source: ASEAN Secretariat, 2019

Life expectancy varies across ASEAN (Figure 4). The average life expectancy in AMS reached 71.4 years in 2017, or an increase of over 2.5 years from 2005. Life expectancy in ASEAN ranges from more than 83.2 years in Singapore, between 70 and 80 years in Brunei Darussalam, Thailand, Malaysia, Vietnam, Indonesia and Cambodia, to under 70 years in the Philippines, Laos and Myanmar. 


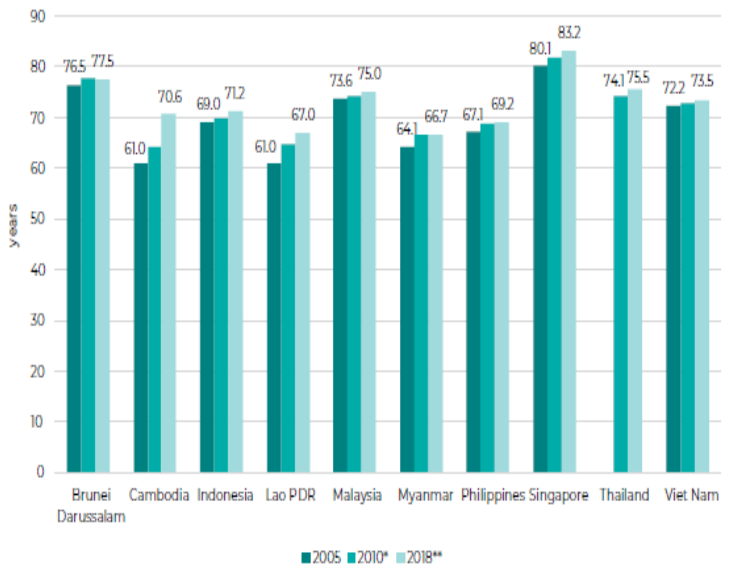

Figure 4. Life Expectancy (years) in ASEAN 2005-2017

Source: ASEAN Secretariat, 2019.

Smoking is a major risk factor that causes a dramatic increase in the incidence of this disease and premature death (Zatoński et al., 2016). The risk of disesases and other premature deaths comes from the consumption of alcoholic beverages and sweetened beverages (Veerman et al., 2016).

The relationship between excise tax policy and the human development index (HDI) was developed from the Rostow and Musgrave models that link fiscal policy development with the stages of economic development, namely the initial, intermediate and advanced stages. Rostow and Musgrave's theories are views that arise from observations of the experience of economic development experienced by many countries but are not based on a particular theory. Besides it is not clear whether the stages of economic growth occur in stages by stages or several stages can occur simultaneously. Education and good health will increase the capacity and independence of life. Education and health play a role in opening up greater opportunities to absorb and manage sources of economic growth (Zahari \& Sudirman, 2017).

Education and health of the population largely determine the ability to absorb and manage the sources of economic growth both in relation to technology to institutions that are important for economic growth. With good education, the use of technology or technological innovation is possible. Health, or more broadly is human capital, can contribute to development. This is because health is factor that facilitate the productive use of human skills, causing the accumulation of human capital and the growth of aggregate output if human capital is an input in the aggregate production function (Ali et al., 2018).

For health problems is a basic need for every human being, without public health can not produce a productivity for the country. A country's economic activities will run if there is health insurance for each of its residents. Developing countries such as Indonesia are 
undergoing a medium stage of development, where the government must provide more public facilities such as health to increase economic productivity. Health facilities and health insurance must be designed in such a way by the government policies.

a. Excise Taxes on Alcoholic Beverages

Alcohol is legal in almost every country in the world, but domestic and international research has shown that drinking alcohol has more negative than positive effects. Alcohol causes disease burden and injury is one of the main factors compared to other risk factors, and according to the World Health Organization, alcohol is the cause of more than 60 diseases, including the overall social and economic impact. Alcohol can be linked to chronic infectious diseases: lung, heart, kidney, liver, cancer and incomplete metabolism, with 60\% of patients with non-communicable diseases finding that all have a history of alcohol consumption.

ASEAN members have realized the importance of human development and health protection through tariff instruments. One of the agendas includes the control of liquor, especially tax measures, free trade agreements, the prohibition of socially responsible marketing communications from liquor companies and illegal alcohol control, because economic integration into individual countries is risky. Therefore, in conducting free trade, free trade must also be safe under the indicators and targets determined by the organization. This includes a focus on individual, family and social actions that determine health behavior and agree to have a network to control alcohol consumption in ASEAN. Related to health is the imposition of taxes on alcoholic beverages. There are eight ASEAN countries that have imposed excise tariffs on alcoholic beverages, namely Indonesia, Malaysia, Singapore, Laos, Vietnam, Myanmar, Cambodia and Thailand.

Internationally, alcohol excise is charged to limit consumption and as a means of overcoming impacts on society associated with risky consumption and high risk (negative externalities). In ASEAN, alcohol excise has various names and is classified in various regimes in government. The official names for alcohol tax in ASEAN include:

- Excise: Indonesia, Singapore, Brunei Darussalam, Laos, Malaysia and the Philippines

- Liquor Tax: Thailand

- Law on Excise Tax: Vietnam

- Specific Tax on Certain Merchandise and Services: Cambodia

- Commercial Tax: Myanmar 
Excise tax structure has changed a lot from time to time by considering various issues such as different levels of development between regions and developmental developments that are partial (not comprehensive).

From the perspective of the excise tax system design, ASEAN countries currently use one or more of the three excise taxation methods for local alcoholic beverages or imported alcoholic beverages, as follows:

- Specific (Volumetric Taxation), the imposition of excise based on the amount of alcohol content in the product measured in liters of pure alcohol (Liters of Pure Alcohol / LPA).

- Unitary Taxation for the imposition of excise based on the total volume of liquids in the product

- Ad Valorem imposition of excise based on product value.

Table 5. Alcohol Excise Tax Structure in ASEAN

\begin{tabular}{lc}
\hline \multicolumn{1}{c}{ Country } & $\begin{array}{c}\text { Products (fermented liquors; distilled spirits; } \\
\text { wines) }\end{array}$ \\
\hline Brunei & Specific (liter) \\
Cambodia & Ad valorem \\
Indonesia & Specific (liter) \\
Laos & Ad valorem \\
Malaysia & Specific (proof liter) \\
Myanmar & Ad valorem for fermented liquors; \\
Specific (liter) for distilled spirits \& wines & Specific (liter) for fermented liquors; \\
Philippines & Ad valorem \& specific (mixed) for distilled \\
& spirits \& wines \\
Singapore & Specific (proof liter) \\
Thailand & Mixed \\
Vietnam & Ad valorem \\
\hline Source: Department of Finance-the Philippines, 2019
\end{tabular}

b. Excise Taxes on Tobacco-based Products

The government generally has two main objectives in establishing tobacco excise tax policies (cigarettes) in the country, namely generating state revenues for the government budget and reducing tobacco consumption for health reasons. An increase in tobacco excise 
reduces deaths and illnesses caused by tobacco use (WHO, 2011). In the short term, the increase in tobacco excise tax will increase state revenue, although in the long run revenue will decrease.

WHO (2016) recommends tobacco tax rates of at least 70 percent of the retail price. This will drive up the price of tobacco products substantially. Furthermore, this increase will have an impact on consumers, namely many consumers will reduce the frequency of smoking and prevent the growth of cigarette consumption in new consumers. Thus, the risk of death and disease caused by tobacco use will decrease. WHO stressed that this increase in excise tax on tobacco products must be greater than other tax rates so that this increase can have a major impact on consumer spending.

The decision to raise tobacco excise taxes must be based on political considerations and consider the impact of tax avoidance (WHO, 2011). In addition, excessive tobacco tax increases can trigger financial fraud. Furthermore, WHO recommends simplifying the structure of the tobacco excise tax. A simpler structure will be easier to manage. It will also prevent tax avoidance and prevent consumers from switching to cheaper tobacco products. In addition, the reduction in variations in tobacco product excise tax policies over time periods leads to uniform excise tax rates.

All of ASEAN members has excise policy for tobacco products. ASEAN member countries are currently applying different bases for the imposition of cigarette excise tax. The following explanation:

- In Singapore and Brunei, there is a pure specific tax system, where excise is charged at a single rate per 1,000 cigarettes;

- Indonesia and the Philippines also have a specific excise tax system but with different excise tax rates. In the case of the Philippines, cigarettes are currently classified into two tariff levels depending on the Net Retail Price. In Indonesia, which has the most complex system in ASEAN and also one of the most complex systems globally, there are several levels of excise tax rates depending on the type of cigarette such as handmade clove cigarettes, machine-made clove cigarettes or conventional cigarettes and furthermore there are sub more categories depending on production volume and estimated retail price;

- Cambodia, Myanmar, and Vietnam have an ad valorem excise tax system based on CIF or Net ExFactory Price;

- Malaysia has a specific and ad valorem mixed system with specific excise components which represent about $95 \%$ of the total excise tax); 
- Thailand has a system where the applicable excise tax is the highest rate between the ad valorem tariff or the specific applicable tariff; and

- Laos has an ad valorem system for domestic cigarettes and a specific system for imports.

ASEAN members apply varying tariffs on tobacco products (Southeast Asia Tobacco Control Alliance, 2015). The highest excise tax burden is set by Thailand at 70 percent, Singapore (66.2 percent), Brunei Darussalam (62 percent), Indonesia (57 percent), Cambodia (31 percent) and Laos (19 percent).

Table 6. Tobacco Excise Policy in ASEAN

\begin{tabular}{|c|c|}
\hline Country & Excise rate \\
\hline Brunei & BND 0.50/stick \\
\hline Cambodia & $20 \%$ of $90 \%$ of invoice price \\
\hline Indonesia & IDR 100-625/stick (10 tiers) \\
\hline Laos & $\begin{array}{l}15-30 \% \text { of production cost, plus LAK } \\
500 \text { additional specic tax (In practice), } \\
\text { LAK } 600 \text { additional specic tax (By } \\
\text { law) } \\
30 \% \text { of retail price }(2016-2017), 45 \% \\
\text { (2018-2019), } 60 \%(2020 \text { onwards), } \\
\text { plus LAK } 600 \text { additional specic tax } \\
\text { (By law) }\end{array}$ \\
\hline
\end{tabular}

Malaysia

MYR 0.40/stick

Myanmar

MMK 6-21/stick (4 tiers)

Philippines

PHP 45.00/pack on 1 January 2020; PHP 50.00/pack on 1 January 2021; PHP 55.00/pack on 1 January 2022; PHP 60.00/pack on 1 January 2023.

Singapore

SGD $0.427 /$ stick

Thailand

$20 \%$ of SRP (if SRP less than/equal to THB 60/pack) plus THB 1.20/stick; $40 \%$ of SRP (if SRP more than/equal to THB 60/pack) plus THB 1.20/stick; $40 \%$ of SRP plus THB 1.20 /stick

Vietnam $75 \%$ ex-factory price Source: Southeast Asia Tobacco Control Alliance, 2019.

c. Excise Taxes on Sugary Beverages 
Non-alcoholic (sweetened) beverages is risk factors for various diseases do not contagious. Morbidity and mortality rates due to the drink is quite high (Shandia, 2016). Problems in the field of health, including non-communicable diseases, deserve serious attention going forward, because health is a basic capital which is very influential on human development outcomes. Therefore, the health aspect becomes an important consideration for policy makers in ASEAN countries, including by controlling sugar consumption through excise policies.

The application of excise to non-alcoholic beverages aims to overcome the negative externalities of beverages containing carbonated sugar sweeteners. The current excise tax on non-alcoholic beverages is seen as an easy way to increase state revenue. The policy of controlling sweetened beverages through excise is a long-term investment. This is by considering health factors. With the imposition of excise, the risk of health problems caused by the consumption of sweetened beverages can be effectively prevented while increasing revenue from the excise taxes.

Establishing excise duty on non-alcoholic beverages can increase excise revenue. However, tax policy makers need to be careful in ensuring the impact of policies made on other tax revenues that will affect overall tax revenue. The higher the excise tax, the daily consumption of sweetened non-alcoholic beverages will decrease. The economic benefits derived from sweetened beverages in the form of taxes are always smaller than the health losses incurred (FEUI, 2013). Sweetened beverages have become the focus of control in ASEAN. Until now, there are 7 ASEAN members imposing excise on sugary drinks, namely Brunei Darussalam, Cambodia, Laos, Malaysia, Myanmar, the Philippines and Thailand (Preece, 2019).

Thailand have made an extension of excise duty on sugar-sweetened beverages and restructuring tax rates are based on sugar content. Brunei, Malaysia, and Thailand impose a sweetened beverages excise tax based on sugar content, while the Philippines will impose excise based on sugar sources. Cambodia, Laos, PDR and Myanmar continue to impose a tax on the drink based on its value (Preece, 2019).

Table 7. Sweetened Beverages Excise Policy in ASEAN

\begin{tabular}{llc}
\hline Country & Based & $\begin{array}{c}\text { Tax per litre (USD) or ad } \\
\text { valorem rate }\end{array}$ \\
\hline Brunei & $\begin{array}{l}\text { Sugar } \\
\text { content }\end{array}$ & $\$ 0.30$ \\
Cambodia & Value & $10 \%$
\end{tabular}




\begin{tabular}{llc}
\hline Country & Based & $\begin{array}{c}\text { Tax per litre (USD) or ad } \\
\text { valorem rate }\end{array}$ \\
\hline Indonesia & \multicolumn{2}{c}{ Proposed / public consultation } \\
Laos & Value & $5 \%$ \\
Malaysia & $\begin{array}{l}\text { Sugar } \\
\text { content }\end{array}$ & $\$ 0.10$ \\
& Value & $5 \%$ \\
Myanmar & Source of & $\$ 0.12$ \\
Philippines & sugar & $\$ 0.24$ \\
& & Proposed / public consultation \\
Singapore & & $\$ 0.003+14 \%$ \\
Thailand & Sugar & $\$ 0.009+14 \%$ \\
& content & $\$ 0.015+14 \%$ \\
& & $\$ 0.031+14 \%$
\end{tabular}

Source: Preece, 2019

\section{CONCLUSION}

The results showed that the excise tax policy had supported human development in AMS. The human development index in AMS has increased supported by an increase in the health and longevity index, as experienced by Singapore, Brunei Darussalam, Malaysia, and Thailand. This is supported by the existence of an excise tax policy that imposes high tariffs and is imposed on various types of negative products. AMS has implemented an excise policy to protect the health of its citizens through restrictions on the consumption of products that have a negative impact on the health of individuals and society. Goods subject to excise related to health protection include: cigarettes, alcoholic beverages and sweetened beverages. The excise policy in AMS varies with the excise tax rate and the types of goods subject to excise duty. Countries that charge relatively high excise tax rates include: Singapore, Brunei Darussalam, Malaysia, and Thailand. The countries that charge the most variety of negative products are Brunei Darussalam, Malaysia, the Philippines and Thailand. It is possible to suggest that future human development will be related to the excise tax policy at AMS. As income and consumption levels increase, excise policies must focus on protecting negative impacts on people and the environment.

\section{ACKNOWLEDGEMENT}


The author thanked the Ministry of Finance of the Republic of Indonesia for facilitating the data collection to complete this research.

\section{REFERENCES}

Ali, Muhammad, Abiodun Egbetokun, Manzoor Hussain Memon. (2018). Human Capital, Social Capabilities, and Economic Growth, Economies, 6, 2, 118, doi: 10.3390/economies6010002.

Asia Pacific Tax Forum ASEAN Excise Tax Study Group (APTF). (2013). APTF ASEAN Excise Tax Study Group: Including Tobacco, Alcohol, Non-Alcohol \& Automotive Chapters. Discussion Paper http://www.iticnet.org/images/Phase_II_Discussion_Paper.pdf

ASEAN Secretariat. (2019). ASEAN Key Figures 2019. Jakarta: ASEAN Secretariat.

Budilaksono, Agung \& Rustiningsih, H. (2013). Analisis Kebijakan Tarif Cukai Rokok dalam Menghadapi Pasar Tunggal ASEAN Economic Community 2015. Jakarta: Badan Pendidikan dan Pelatihan Keuangan.

Chandra, Alexander \& Hattari Ruben. (2014). Taking Advantage of ASEAN's Free Trade Agreements. ASEAN Secretariat.

Cnossen, S. (2015). Int Tax Public Finance 22: 1077. New York: Springer. https://doi.org/10.1007/s10797-015-9348-1

Community Relations Division the ASEAN Secretariat. (2018). ASEAN Statistical Highlights 2018. Jakarta: ASEAN Secretariat. October 2018. https://www.singstat.gov.sg/-/media/files/publications/reference/ASEAN-statisticalhighlights-2018.pdf, accessed 5 April 2019.

Cristes L.A. (2017). The Share and Evolution of Indirect Taxes in the State's Revenue-Case of Romania. "Annals of the University of Petorsani - Economics", 17 (1).

Department of Finance of the Republic of the Philippines. 2019. Package 2+ Alcohol Excise Tax Reform. http://taxreform.dof.gov.ph/publication/recent-presentations/. Accessed 04 December 2019.

Drozdek, A. (2019). Right To Reimbursement of Excise Duty Versus Tightening of Tax System Through Interpretation of Law. Ius Novum (Vol. 13) 3, 177-194. Doi: 10.26399/iusnovum.v13.3.2019.36/a.drozdek

Falbe, Jennifer, Hannah $\quad$ R. Thompson, Christina $\quad$ M. Becker, Nadia Rojas, Charles E. McCulloch, Kristine A. Madsen. (2016). Impact of the Berkeley Excise Tax on Sugar-Sweetened Beverage Consumption. American Journal of Public Health 106, no. $10.1865-1871$. 
FEUI. (2013). Profil Industri Minuman Ringan Dan Dampak Ekonomi Pengenaan Cukai Pada Minuman Berkarbonasi. Jakarta: FEUI.

Guthrie, J, L. Mancino, C.J. Lin. (2015). Nudging Consumers toward Better Food Choices: Policy Approaches to Changing Food Consumption Behaviors. Psychol Mark, Volume 32, issue 5, 501-511. https://doi.org/10.1002/mar.20795.

Ho, L., C. Schafferer, J. Lee, C. Yeh, C. Hsieh. (2018). Raising Cigarette Excise Tax to Reduce Consumption in Low-And Middle-Income Countries of the Asia-Pacific Region: A Simulation of the Anticipated Health and Taxation Revenues Impacts. BMC Public Health 18, 1187. doi: 10.1186/s12889-018-6096-z

IMF. (2018). IMD Data Mapper: World Economic Outlook (October 2018). https://www.imf.org/external/datamapper/NGDP_RPCH@WEO/WEOWORLD/SEQ, accessed 5 April 2019.

Iglesias RM. (2016). Increasing excise taxes in the presence of an Illicit cigarette market: the 2011 Brazil tobacco tax reform. Rev Panam Salud Publica. 40(4).

Ismer, R., \& Piotrwki, S. (2018). Selectivity in Corporate Tax Matters After World Duty Free: A Tale of Two Consistencies Revisited. Intertax, 46(2), 156-166.

Le Cacheux J., Laurent E. (2015). Taxation in the EU: Fiercer Competition?. In: Report on the State of the European Union. Palgrave Macmillan, London. Doi: https://doi.org/10.1057/9781137451088_4

Li, Dingsheng \& Sangwon Suh. (2019). Health risks of chemicals in consumer products: A review, Environment International, Volume 123, 580-587. https://doi.org/10.1016/j.envint.2018.12.033.

Maulana, C. B. I. (2019). Law Enforcement Policy on Violation of Illegal Cigarette Circulation in Indonesia (Study on Indonesian Customs Directorate General). JILS (Journal of Indonesian Legal Studies), 4(01), 103-118. https://doi.org/10.15294/jils.v4i01.29176

Mononi, G. (2015). The Effectiveness of the Alcohol Levy on Drinking Trends in Botswana: The Case of Gaborone. Unpublished MBA Thesis. Northwest University.

Preece, Rob. (2015). Automotive Excise Taxation: What Reforms are Needed to Best Utilise The ASEAN Economic Community? World Customs Journal, Vol.9, number 1, 15-36.

Preece, Rob. (2019). Excise Tax Reforms Across ASEAN since the Start of Its Economic Community. World Customs Journal, Volume 13, Number 1: 9-26.

PwC. (2018). The Future of ASEAN-Time to Act (May). Singapore. 
Rosdiana, Haula \& Slamet Edi Irianto. (2012). Pengantar Ilmu Pajak: Kebijakan dan Implementasi di Indonesia, Jakarta: Penerbit Rajawali Press.

Shandia, May. (2016). Asean Region: 2016 Food and Non-Alcoholic Beverage Tax Updates. International Tax and Investments Center.

Schneider, A. (2015). Political economy of citizenship regimes: Tax in India and Brazil. UNRISD (Working Paper No. 11, July).

Southeast Asia Tobacco Control Alliance. (2015). Implementation of WHO Framework Convention on Tobacco Control Article 6 in ASEAN Countries. Bangkok: Southeast Asia Tobacco Control Alliance SEATCA.

Southeast Asia Tobacco Control Alliance. (2019). SEATCA Tobacco Tax Index: Implementation of WHO Framework Convention on Tobacco Control Article 6 in ASEAN Countries, 2019. Bangkok. Thailand.

Task Force on Fiscal Policy for Health (2019). Health Taxes to Save Lives: Employing Effective Excise Taxes on Tobacco, Alcohol, and Sugary Beverages. Chairs: Michael R. Bloomberg and Lawrence H. Summers. New York: Bloomberg Philanthropies. Available at: https://www.bloomberg.org/program/public-health/taskforce-fiscal-policy-health/

Teixeira, Aurora A.C. \& Anabela S.S. Queirós. (2016). Economic Growth, Human Capital and Structural Change: A Dynamic Panel Data Analysis. Research Policy, Volume 45, Issue 8, 1636-1648. https://doi.org/10.1016/j.respol.2016.04.006.

Veerman JL, Sacks G, Antonopoulos N, Martin J. (2016). The Impact of a Tax on SugarSweetened Beverages on Health and Health Care Costs: A Modelling Study. PLoS ONE 11(4): e0151460. https://doi.org/10.1371/journal.pone.0151460

World Health Organization. (2011). WHO Technical Manual on Tobacco Tax Administration. Geneva: WHO Press, World Health Organization.

Zatoński, M., Witold A. Zatoński, Krzysztof Przewoźniak, Marek Jaworski. (2016). The Significance and Impact of The Polish Anti-tobacco Law. Journal of Health Inequalities, 2 (1). DOI: 10.5114/jhi.2016.61417.

Zahari, MMS \& Sudirman. (2017). The Effect of Government Expenditures in Education and Health against Human Development Index in Jambi Province. The International Journal of Social Sciences and Humanities Invention 4(8): 3823-3829. doi: 10.18535/ijsshi/v4i8.21. 